\title{
РАЗВИТИЕ СФЕРЫ ОБЩЕСТВЕННОГО ПИТАНИЯ ИРКУТСКОЙ ОБЛАСТИ В 1990-2010 ГОДАХ
}

В статье проанализировано развитие системы общественного питания Иркутской области в постсоветский период. Несмотря на все трудности развития отрасли, общественное питание в регионе было достаточно широко развито: в большинстве крупных населенных пунктов были представлены предприятия разного профиля, ценового диапазона и объема обслуживания посетителей. За два десятилетий система общественного питания пережила серьезную трансформацию: от привычных, в советский период, столовых, кафе, пельменных, блинных и позных к современным ресторанам быстрого питания, закусочным «бистро», экзотическим кафе и т.д.

Ключевые слова: сфера общественного питания, ресторанный бизнес, фраст-фуд.

\section{DEVELOPMENT OF THE SPHERE OF PUBLIC CATERING THE IRKUTSK REGION IN 1990-2010}

The article analyzes the development of the catering system of the Irkutsk region in the post-Soviet period. Despite all the difficulties in the development of the industry, catering in the region was widely developed: in most large settlements were represented by enterprises of different profiles, price range and volume of customer service. For two decades, public power has experienced a major transformation: from the usual in the Soviet period, canteens, cafes, dumplings, pancake to modern fast food restaurants, eateries and bistro, exotic cafes, etc.

Keywords: catering, restaurant business, fast food.

В Иркутской области в 1990-2000 гг. произошла серьезная трансформация предприятий общепита: от привычных в советский период столовых, кафре, пельменных, блинных и позных к современным ресторанам быстрого питания, закусочным «бистро», экзотическим кафе и т.д.

О том, как начинал свой ресторанный бизнес, рассказывал армянин из г. Иркутск Р. Карапетян. - Появилась у меня такая идея - кавказские шашлыки. В Иркутске в 1992-1993 гг. был ресторан «Азия». Первый мангал я поставил в Солнечном и на улице Байкальской, сейчас на этом месте кафе «Армавир». В течение полутора месяцев те два ман- 
гала дали больше выручки, чем ресторан «Азия». Взяли мы на рынке деревянный киоск два на два, обшили его железом, покрасили, утеплили и начали торговать. А после уже и из этого окна, стали продавать сигареты, спиртные напитки. Поставили еще киоски на проспекте Карл-МарксШтадт, на улице Волжской, построили шашлычную «Маяк». В 1994 г. у нас уже было шесть объектов. А в 1995-м начали строить кафе «Кристина» в районе аэропорта. Начали с железного павильона размером четыре на шесть, один мангал поставили. К 2000 г. «Кристина» уже стала целым комплексом: ресторан, ночной зал, банкетный, бистро [8, с. 2].

Вместе с тем в развитии сореры общественного питания Приангарья наблюдались свои проблемы. Так в 1998 г. по сообщению пресс-службы Иркутского центра стандартизации, метрологии и сертификации, отделом государственного надзора за квартал было проверено 119 предприятий различных форм собственности на соблюдение обязательных требований государственных стандартов и правил обязательной сертификации. На 78 предприятиях были выявлены различные нарушения. В том числе в 63 случаях производилась реализация продукции без сертификатов соответствия, в четырех - с поддельными сертификатами. Из 29 проверенных предприятий общепита 24 явились злостными нарушителями установленных правил и норм. Их главный грех - в оказании несертифицированных услуг, нарушении рецептуры и санитарных норм [13, с. 3].

За 10 лет (с 1990 по 2000 г.) в Приангарье оборот общепита сократился в 4,4 раза. Только в середине 2000 г. наметились положительные сдвиги, годовой оборот оказался на 4 \% выше, чем в 1999 г. Однако закрепить успех не удалось. В 2001 г. доходность предприятий общественного питания вновь снижалась, падение составило 2 \% [10, с. 2].

Сократилось число точек общепита в организациях, учебных заведениях и общежитиях. Им на смену пришли небольшие уютные закусочные и кафе, За 10 месяцев 2001 г. суммарная выручка всех ресторанов, буфетов, столовых и кафе области превысила 1,6 млрд р. Все величие этой суммы «таяло» при делении ее на число жителей Иркутской области и указанный временной отрезок. На душу населения приходилось по 60 р. в месяц. Из 12 регионов Сибирского федерального округа это был третий результат. Опережали иркутян только красноярцы и кемеровчане.

Из высоких цен на продукты слагалась немалая стоимость питания. Например, в 2001 г. обед из трех блюд в столовых г. Ангарска «тянул» на 33 р., в областном центре - стоил вдвое дороже. Обед в рабочей столовой иркутянам рабочим обходился дешевле (26 р.). А в ресторане на обед не хватило бы и 200 р.

Отдельные успешные предприниматели даже в этих условиях умудрялись получать прибыль, но отрасль в целом в течение ряда лет была 
убыточна. Если в других сферах деятельности число убыточных предприятий медленно, но верно снижалось, то в этом непростом деле продолжало нарастать. Количество «неудачников», не сводящих концы с концами, составило 56 \%. Пытаясь выжить, общепит вторгался в смежные сферы, занимаясь и оптовыми перепродажами, и торговлей в розницу.

И в былые времена общепит не был щедр по отношению к своим работникам. В 2001 г. оплата труда в отрасли - была одной из самых низких (1,5 тыс. р.), занятые розничной торговлей ежемесячно получали на 500 р. больше. А в сравнении со средне-областным уровнем «работники кухни» зарабатывали меньше в 2,5 раза [10, с. 3].

В 2001 г. распахнул двери отремонтированный уголок общепита в муниципальном предприятии «Иркутсктеплоэнерго». Это был один из первых шагов к возрождению старой доброй традиции - кормить работников предприятия вкусно и недалеко от работы. Горячие обеды, приготовленные здесь опытными поварами, доставлялись по заказу на подразделения предприятия [4, с. 2].

Однако встречались и негативные пример работы предприятий общепита. Так, например, услуги питания, оказываемые столовой унитарного предприятия «Завод Коммунальник» (г. Иркутск) на улице Рабочего штаба, проверялись Иркутским центром стандартизации и метрологии неоднократно. В 2001 г. в нарушение Закона о защите прав потребителей услуги не были сертифицированы. Были выявлены и другие нарушения, в частности, в столовой использовались негодные весы. Предписание Иркутского ЦСМ обязывало руководство завода приостановить работу столовой до устранения нарушений $[12$, с. 3].

В городах Иркутской области продолжалась приватизация крупных точек общепита. Так, в 2002 г. часть муниципального имущества г. Саянска была выставлена на продажу. Такое решение приняла городская Дума по инициативе администрации Саянска в связи с тем, что часть муниципального имущества простаивала и приносила убытки местному бюджету. В частности, на аукцион было выставлено помещение кафе клуба «Строитель», пустующее на протяжении семи лет. Оно было продано за 440 тыс. р. (начальная цена объекта составляла 434 тыс. р.). Победителем конкурса стал частный предприниматель из г. Черемхова. По условиям сделки в будущем помещение было использовано только в сорере общепита [9, с. 2].

В 2003 г. Центр стандартизации и метрологии проверил оказание услуг общественного питания в областном центре. Многие предприниматели нарушали рецептуру, умалчивали об использовании консервантов, имели сомнительные сертификаты. Даже в столовых, где проходил большой поток посетителей, — к примеру, в Иркутском государственном лингвистическом университете, - не соблюдалась технология приготовления пищи, режим обработки сырья, товарное соседство, санитарные правила. 
Хотя обслуживание и перешло в руки частников, новые хозяева благополучно унаследовали от социалистического общепита «три кита», на которых он держался: обман, обвес, недовложения.

Предприниматели «не стеснялись» сбывать продукцию с истекшим сроком годности. Часто его просто невозможно было узнать. Особенно при продаже скоропортящихся кондитерских изделий. Так предприниматель Н. Лаптева хранила пирожные «Профритроли», торты «Пчелка» и «Тутти-фррутти» не в холодильнике, а при комнатной температуре, и дату изготовления не указывала. А в ООО «Ами-2» не только не указали дату изготовления выпечки, но еще и поставили срок хранения 30 суток вместо пяти [4, с. 9].

Крупные торговые сети все чаще для расширения площадей в центре Иркутска использовали объекты культурного наследия. Только в Кировском районе в 2005 г. было введено три коммерческих центра, которые расположились в архитектурных памятниках. Эксперты говорили о наметившейся тенденции к размещению новых объектов торговли и общепита именно в реконструированных и восстановленных исторических зданиях [5, с. 3].

В 2007 г. специалисты управления Роспотребнадзора по Иркутской области начали комплексные проверки на предприятиях торговли и общепита придорожного сервиса. В частности, в придорожных кафе и магазинах проверяли наличие документов, качество и безопасность сырья и реализуемой продукции. В результате проверок на территории области были отмечены такие недостатки, как отсутствие утвержденных планов дислокации мелкорозничной сети, установка прилавков на газонах и тротуарах, использование в качестве торгового оборудования ящиков и коробок. Особые нарекания Роспотребнадзора вызвала эксплуатация летних кафе при отсутствии водоснабжения, канализации, без достаточного оснащения холодильным оборудованием, а также реализация продуктов и напитков с истекшим сроком годности. По итогам проверок было забраковано 105,6 т плодоовощной продукции, которую реализовали без сопроводительных документов. Были сняты с реализации в летних кафе 112 кг рыбной продукции, хранящейся с нарушением температурных режимов. Было забраковано 7,3 тыс. л пива и кваса с истекшим сроком годности [11, с. 3].

В 2008 г. в Иркутске работало 150-170 различных закусочных с общим количеством посадочных мест порядка 6 тыс., но в отделе общественного питания городского комитета по потребительскому рынку к заведениям фаст-фуда относили только 13 из них, где могли разместиться 650 чел.

По офрициальным данным, обеспеченность Иркутска заведениями быстрого питания равнялась 40-42 посадочных места на 1 тыс. чел., что составляло 50-55 \% от данных в среднем по России. 
«Появление предприятий стрит-фуда имело несколько преимуществ, - говорил директор сети «12 месяцев» Н. Борисенко. - Удобно для людей, которые спешат: не нужно никуда заходить, отвлекаться. Наглядно: клиент видит, как готовится еда для него. На обслуживание одного посетителя уходило порядка четырех минут».

Большая часть иркутских заведений стрит-фуда рассчитывала на постоянных клиентов из числа горожан, поэтому в меню присутствовали национальные блюда - блины, супы, пирожки. Ставку на национальный колорит делало и «Чудо-блюдо», 90 \% клиентов кафе были местными жителями [6, с. 3].

В 2009 г. по словам владелицы ресторана С. Новоселовой: «все думали о закрытии своих заведений, но продать было некому, а бросить жалко». Обороты местных заведений общественного питания потеряли за начало 2009 г., по официальным данным, до 10 \%, а по подсчетам самих игроков - до 50-60 \%. Рестораторы пробовали «умерить аппетиты», предлагали антикризисные бонусы, но с сожалением замечали, как их клиенты уходили в кафе, закусочные и фаст-фуды. От последних до домашнего питания был один шаг, были уверены эксперты.

По данным управления бытового обслуживания общественного питания и защиты прав потребителей г. Иркутска, на начало 2009 г. наименьшая доля была представлена буфетами - $2 \%$ и ресторанами $5 \%$; наибольшая: кафе - 29 \% и столовыми - $23 \%$.

Генеральный директор ресторана «НЭП» А. Бондарь следила за снижением потока клиентов с осени 2008 г. «В отдельных случаях мы даже стали разрешать приносить с собой свой алкоголь», - говорила ресторатор. В ее заведении уже были вынуждены сократить персонал. Слова ресторатора подтверждала статистика: оборот общественного питания в Иркутске и области в первом квартале 2009 г. составил 1,8 млрд р., или 727 р. на душу населения. Это было на 10,5\% меньше, чем за аналогичный период 2008 г., свидетельствовал Иркутскоблстат.

Сами иркутяне подтверждали, что в предприятия общепита стали заходить реже и тратить там меньше денег. «Раньше 4-5 тыс. р. в месяц уходило на «посиделки» различные в кофейнях-ресторанах-кафе, а теперь я иду либо с людьми, которые за меня заплатят, либо ограничиваюсь кофе с десертом в пределах 500 р. за поход», - рассказала дизайнер Жанна. По словам другого собеседника, «иногда все же приходится посещать заведения, чтобы встретиться по делам». «К любви к домашней еде теперь добавилась финансовая составляющая. Так что домой, там поесть - и назад на работу. Благо, что близко», - добавил другой собеседник [1, с. 4].

«Выжить в кризис смогли предприятия, проявившие максимум организаторского таланта, - был уверен начальник отдела общественного питания комитета по потребительскому рынку Иркутска М. Волынец. - 
В выигрыше остались предприятия, ориентированные на потребителя со средним уровнем достатка, потому что к ним перетекли клиенты из более дорогих заведений» [7, с. 2].

Вместе с тем, «росли на обочинах дорог» торговые павильоны, шашлычные, чебуречные, позные. К примеру, на улице Трактовой (г. Братск), в таких заведениях наблюдалась антисанитария. Обслуживающий персонал работал без санитарных книжек и специальной профессиональной подготовки. В летнее время на работу принимали студентов и учащихся. Специалисты Роспотребнадзора подтвердили, что уровень придорожного сервиса в Иркутской области был невысок. На многих предприятиях торговли и общественного питания нарушались санитарные требования и ущемлялись права потребителей.

В летний период 2008 г. было обследовано 34 предприятия общественного питания и пять торговых точек на трассах Иркутск - MPC, Листвянка, Ангарск, Шелехов. У проверяющих оказалось много вопросов: есть ли в закусочных, кафе и магазинах водоснабжение и канализация, технологическое и холодильное оборудование? Имелись ли документы, подтверждающие качество и безопасность готовой продукции, а у персонала - медицинские книжки? Соблюдались ли условия и сроки реализации блюд? Была ли благоустроена прилегающая территория?

Во время проверок были выявлены многочисленные нарушения требований санитарного законодательства. На 12 предприятиях индивидуальных предпринимателей не было водоснабжения и канализации, помещений, где готовились многокомпонентные блюда.

Из-за недостаточного оснащения холодильным оборудованием сырье и полуфабрикаты хранились вместе, что было запрещено санитарными нормами. На реализуемую продукцию не было документов, подтверждающих качество и безопасность, в том числе, и на алкоголь (ООО «Ширван», ИП Оглоблина). В ООО «Сибирская заимка» повара работали без медицинских книжек. До потребителей не доводилась информация об услугах. В меню не указывался вес и объем отпускаемых блюд. По результатам проверок было снято с реализации 60 кг продукции. 30 должностных лиц и индивидуальных предпринимателей было оштрафовано [2, с. 3].

Несмотря на все трудности развития отрасли, общественное питание в регионе было достаточно широко представлено: в большинстве крупных населенных пунктов работали предприятия общественного питания разного уровня, направления, разных концепций, кухонь, ценовых категорий. Широкое развитие получили так называемые сетевые рестораны, имеющие единую концепцию: запоминающийся бренд, унифицированное меню, схожий интерьер, единую униформу персонала, расположенные в многолюдных местах, что обеспечивало известность, узнаваемость и большую проходимость. Развитие предприятий общепита продолжалось, что объяснялось востребованностью услуг и высокой 
инвестиционной привлекательностью, быстрой оборачиваемостью вложенных средств.

К 2010 г. индустрия общественного питания в регионе представляла собой огромное количество предприятий с различным уровнем обслуживания, качеством продукции, разнообразием используемого оборудования. Общественное питание оставалось весьма развивающимся направлением пищевой отрасли. Росло не только число самих предприятий общепита, но заметно расширялся их диапазон.

\section{Список использованной литературы и источников}

1. Арбузова Е. Кушать продано / Е. Арбузова // Конкурент. - 2009. 23 мая. - C. 4.

2. Артемьева Л. Счет ресторанам / Л. Артемьева // СМ-номер один. 2008. - 22 окт. - С. 3.

3. Возрождение вкусных традиций // Пятница. - 2001. - 3 июля. - С. 2.

4. Григорьев В. Пельмени по-общепитовски / В. Григорьев // Аргументы и факты в Восточной Сибири. - 2003. - 9-16 авг. - С. 9.

5. Давыдова Е. Общепит в доме-памятнике / Е. Давыдова // Пятница. 2005. - 15 окт. - С. 3.

6. Лисовская Е. Еда с ускорением / Е. Лисовская // Конкурент. - 2008. 28 окт. - С. 3.

7. Лисовская Е. Кухня по-новому / Е. Лисовская // Сибирский энергетик. 2009. - 17 янв. - С. 2.

8. Мазурова С. Роберт Карапетян: «Это только начало в моем бизнесе» / С. Мазурова // СМ-номер один. - 2000. - 23 дек. - С. 2.

9. Муниципальное имущество - с молотка // Саянские зори. - 2002. 13 окт. - С. 2.

10. Овсянникова И. Новое лицо общепита / И. Овсянникова // Восточно-Сибирская правда. - 2001. - 27 нояб. - С. 2.

11. Опасный общепит // Вечерний Иркутск. - 2007. - 17 июля. - С. 3.

12. Шемякин В. Кормят, да и ладно / В. Шемякин // Копейка. - 2002. 11 нояб. - С. 3.

13. Этот грешный общепит // Пятница. - 1998. - 11 июля. - С. 3.

\section{Информация об авторе}

Урожаева Татьяна Петровна - кандидат исторических наук, учитель истории и обществознания, Средняя общеобразовательная школа № 11, 666682, Иркутская область, г. Усть-Илимск, пр-т Дружбы Народов, 70; e-mail: olgoy@ya.ru

\section{Author}

Tatiana P. Urozhaeva - PhD in History, Teacher of History and Social Science Middle School of General Education No 11; 70, Druzhba Narodov St., 666682, Ustllimsk, Irkutsk oblast, Russia; e-mail: olgoy@ya.ru 